\title{
Bradley Fighting Vehicle: Heat in the Driver's Compartment
}

\author{
Margaret S. Salter \\ U.S. Army Research Institute \\ David E. Eakin \\ Auburn University \\ Consortium Research Fellows Program
}

Infantry Forces Research Unit

Scott E. Graham, Chief

U.S. Army Research Institute for the Behavioral and Social Sciences 5001 Elsenhower Avenue, Alexandria, Virginia 22333-5600

January 2001

Army Project Number

20262785A790

Personnel Performance and

Training Technology

Approved for public release; distribution is unlimited. 